Економічні науки: збірник наукових праць Луцького національного технічного університету. Серія "Регіональна економіка". Випуск 18 (71). Редкол.: відп. ред. д.е.н., професор Л.Л. Ковальська. Луцьк: ІВВ Луцького НТУ, 2021. 278 с.

7. Dmytrenko M.Y. Korporatyvna kul'tura ta yiyi funktsional'nyy potentsial. Ekonomika, finansy, pravo. (2014). № 9 (88) [in Ukrainian].

8. Synyts'ka O. Korporatyvna kul'tura: zarubizhnyy ta vitchyznyanyy dosvid. Formuvannya rynkovykh vidnosyn v Ukrayini. (2012). № 12. [in Ukrainian].

9. Kam"yans'ka O. Korporatyvna kul'tura v systemi upravlinnya innovatsiynym pidpryyemstvom. Ekonomika ta derzhava. (2010). № 8 [in Ukrainian].

DOI: https://doi.org/10.36910/2707-6296-2021-18(71)-20

УДК 005.95

Стрижеус Л.В., Тендюк А.О., Марчук Ю.С.

Луцький національний технічний університет

\title{
ТЕОРЕТИКО-МЕТОДИЧНІ ЗАСАДИ ПІДВИЩЕННЯ ЕФЕКТИВНОСТІ МЕНЕДЖМЕНТУ ПЕРСОНАЛУ ОРГАНІЗАЦІї
}

У публікації проведене дослідження теоретичних та методичних аспектів менеджменту персоналу організації, обгрунтовано його сутнісну характеристику, зміст та значення. Виокремлено основні функції менеджменту персоналу організації. Охарактеризовано методичні підходи до оцінки ефективності менеджменту персоналу організації.

Ключові слова: організація, персонал, ефективність, менеджмент персоналу, продуктивність персоналу, кадрова політика.

Stryzheus L., Tendyuk A., Marchuk Yu.

\section{THEORETICAL AND METHODOLOGICAL BASIS OF INCREASING THE EFFICIENCY OF THE PERSONNEL MANAGEMENT OF THE ORGANIZATION}

The publication studies the theoretical and methodological aspects of personnel management of the organization, substantiates its essential characteristics, content and significance. The main functions of personnel management of the organization are highlighted. Methodical approaches to assessing the effectiveness of personnel management of the organization are described. It is indicated that personnel management in modern conditions is an important element in the overall management system of the organization. It has been proven that the art of management not only of the organization, but also of its employees is an important indicator of the economic formula for success in business. It is noted that the poorly 
Економічні науки: збірник наукових праць Луцького національного технічного університету. Серія "Регіональна економіка". Випуск 18 (71). Редкол.: відп. ред. д.е.н., професор Л.Л. Ковальська. Луиьк: ІВВ Луцьького НТУ, 2021. 278 с.

chosen concept of personnel management leads to conflicts. They create a tense atmosphere in the team, interfere with the productive work of employees of the organization. It is noted that personnel management will be based on modern procedures, methods, functions and principles of effective management of the organization. Management has individual specifics, elements of technology, approaches and components. It is determined that the specific features of personnel management are determined by the real conditions of the organization, on the basis of which it is advisable to choose the appropriate personnel strategy. It is noted that personnel management as a direction of professional activity has a great applied value, as it not only provides the organization with personnel, but also is responsible for its productive professional and internal development. It is proven that the development of personnel management of the organization uses a wide range of functions. It is determined that there are certain exceptions, taking into account the specifics of the functioning of the organization in the absence of special positions in the management structure. It is proved that the effective staffing of the organization, the optimal use of staff potential and its professional and social development are the main goals of the formation of personnel management system. It is noted that when assessing the effectiveness of personnel management of organizations, a set of external and internal factors is taken into account, so it is also advisable to use regression models. It is substantiated that the effectiveness of personnel management has a direct impact on the level of costs of the organization and the quality of its activities in general. It is confirmed that the diagnosis of available human capital at different levels of the management hierarchy of the organization in today's environment is important because it not only demonstrates the skills, abilities and knowledge of management, but also to identify potential opportunities and abilities. It is noted that the existing assessment methods are characterized by significant ambiguity and versatility, which allows them to be grouped by classification. It is substantiated that in modern conditions it is impossible to form a universal only correct methodological approach to assessing the effectiveness of personnel management of the organization, as it must be aimed at the strategic goals and objectives of a particular organization. As a result of systematization of theoretical bases of increase of efficiency of management of the personnel of the organization it is revealed that in modern conditions of rapid changes in market economy the main factors of growth become universal skills, qualification, adaptability, productivity and innovation.

Key words: organization, personnel, efficiency, personnel management, personnel productivity, personnel policy.

\section{Стрижеус Л.В., Тендюк А.А., Марчук Ю.С.}

\section{ТЕОРЕТИКО-МЕТОДИЧЕСКИЕ ОСНОВЫ ПОВЫШЕНИЯ ЭФФЕКТИВНОСТИ МЕНЕДЖМЕНТА ПЕРСОНАЛА ОРГАНИЗАЦИИ}

В публикации проведено исследование теоретических и методических 
Економічні науки: збірник наукових праць Луцького національного технічного університету. Серія "Регіональна економіка". Випуск 18 (71). Редкол.: відп. ред. д.е.н., професор Л.Л. Ковальська. Луиьк: ІВВ Луиького НТУ, 2021. 278 с.

аспектов менеджмента персонала организации, обоснована его сущностная характеристика, содержание и значение. Выделены основные функции менеджмента персонала организации. Охарактеризованы методические подходы к оценке эффективности менеджмента персонала организации.

Ключевые слова: организация, персонал, эффективность, менеджмент персонала, производительность персонала, кадровая політика.

\section{Постановка проблеми у загальному вигляді та її} зв'язок 3 важливими науковими та практичними завданнями. Менеджмент персоналу в умовах сьогодення $\epsilon$ важливим елементом в системі загального менеджменту організації. Саме від якості управління залежать успішність організації в довгостроковій перспективі. Тому мистецтво управління не лише організацією, але й іiі співробітниками $є$ важливим показником економічної формули успіху в бізнесі.

Менеджмент персоналу організацій здійснюється в межах організаційних структур управління, завдяки чому забезпечується цілеспрямований систематичний вплив на поведінку персоналу, а також на механізм взаємовідносин між ними. Організаційна структура управління має на меті сприяти ефективному та продуктивному управлінню трудовим потенціалом та усією організацією на основі застосування методів та функцій менеджменту. Організаційна форма визначає лінію організаційної поведінки учасників трудового колективу, в той час як вибір стилю керування та методів менеджменту зумовлюють побудову певної організаційної структури.

Невдало вибрана концепція менеджменту персоналу призводить до конфліктів, що створюють напружену атмосферу в колективі, заважають продуктивній роботі співробітників організації. Тому менеджменту організацій надзвичайно важливо об'єктивно оцінювати існуючі умови праці, специфіку діяльності, особливості трудового колективу, і відповідно, виходячи з цього, формувати власний алгоритм управління.

Аналіз останніх досліджень, у яких започатковано вирішення проблеми. Науковою спільнотою висвітлені основні теоретико-методичні аспекти менеджменту персоналу організації. Вченими детально досліджено економічну сутність, значення та зміст менеджменту персоналу організації, якісну 
Економічні науки: збірник наукових праць Луцького національного технічного університету. Серія "Регіональна економіка". Випуск 18 (71). Редкол.: відп. ред. д.е.н., професор Л.Л. Ковальська. Луиьк: ІВВ Луиького НТУ, 2021. 278 с.

структуру персоналу, питання оцінки рівня забезпеченості та ефективності використання трудових ресурсів. Суттєвий внесок у розвиток проблематики менеджменту персоналу зробили Н. Бондаренко, А. Величко, М. Виноградський, Н. Гавкалова, В. Данюк, А. Кібанов, А. Колот, О. Крушельницька, С. Олійник, А. Силаєв, В. Петюх, С. Цимбалюк та ін. Разом 3 тим, мають місце проблемні питання, які пов'язані 3 підвищенням ефективності менеджменту персоналу організації, що визначило тему дослідження та його своєчасність.

Цілі статті: науково-методичне обгрунтування теоретичних положень щодо підвищення ефективності менеджменту персоналу організації та розробка рекомендацій щодо їх реалізації.

Виклад основного матеріалу дослідження 3 повним обгрунтуванням отриманих наукових результатів. Менеджмент персоналу базуться на сучасних процедурах, методах, функціях та принципах ефективного управління організацією, а також має індивідуальну специфіку, елементи технології, підходи та складові.

Аналіз поглядів науковців та практиків щодо наукового обгрунтування управлінської діяльності дозволив виокремити основні підходи до визначення сутності менеджменту персоналу організації.

Як зазначає В. Горфінкель, «управління працівниками реалізується системним, планомірним, організованим впливом, сукупністю взаємопов'язаних організаційних, економічних та соціальних заходів, створенням умов нормального розвитку та використання потенціалу робочої сили на рівні підприємства» [1].

А. Файолем, Г. Емерсоном, Ф. Тейлором та Г. Фордом менеджмент персоналу трактується як «комплексна прикладна наука про чинники, способи та методи впливу на персонал підприємства» [2].

На думку М. Виноградського, менеджмент персоналу спрямований «на ефективне використання людей (персоналу) 3 метою досягнення як індивідуальних цілей, так і цілей 
Економічні науки: збірник наукових праць Луцького національного технічного університету. Серія "Регіональна економіка". Випуск 18 (71). Редкол.: відп. ред. д.е.н., професор Л.Л. Ковальська. Луиьк: ІВВ Луцьького НТУ, 2021. 278 с.

організації» [3].

Як стверджує М. Суровкін, менеджмент персоналу доцільно трактувати як «діяльність, що здійснюється окремими та спрямована на реалізацію стратегічної мети розвитку підприємства, а також на виконання тактичних завдань 3 ефективного використання зайнятих на підприємстві працівників» [4].

На думку А. Колота під менеджментом персоналу варто розуміти «цілеспрямований вплив на працівників підприємства, метою якого $€$ досягнення максимальної відповідності можливостей персоналу цілям, стратегіям і умовам розвитку організації» [5].

Менеджмент персоналу включає в себе комплекс методів організаційно-розпорядчого, соціально-психологічного, та економічного характеру, що пов'язані між собою та забезпечують ефективність роботи персоналу, його конкурентоспроможність та конкурентоздатність організації.

Специфічні риси менеджменту персоналу визначаються реальними умовами діяльності організації, виходячи 3 яких доцільно обирати відповідну кадрову стратегію.

Менеджмент персоналу як напрям професійної діяльності має велике прикладне значення, оскільки не лише забезпечує організацію персоналом, але й несе відповідальність за його продуктивний професійний i внутрішньо-організаційний розвиток, створення безпечних умов для роботи, а також ефективне стимулювання. Зазначене вище вимагає чітких та злагоджених інформаційних і організаційних зв'язків суб' єктів менеджменту персоналу з усіма функціональними службами та підрозділами організації. Тому систему менеджменту персоналу доцільно формувати на засадах патерналізму.

Технологія менеджменту персоналу організації використовує широкий спектр функцій, базовими серед яких є:

1) відбір персоналу приймання, наймання персоналу;

2) навчання кадрів, їх перепідготовка та підвищення кваліфікації;

3) дотримання етики ділових відносин та мотивація 
Економічні науки: збірник наукових праць Луцького національного технічного університету. Серія "Регіональна економіка". Випуск 18 (71). Редкол.: відп. ред. д.е.н., професор Л.Л. Ковальська. Луиьк: ІВВ Луиького НТУ, 2021. 278 с.

праці;

4) управління стресами та конфліктами в організації;

5) ділова оцінка персоналу в процесі добору, приймання та атестації;

6) трудова адаптація та професійна орієнтація;

7) управління соціальним розвитком трудового колективу.

Існують певні виключення, які враховують специфіку функціонування організації за умови відсутності у структурі управління спеціальних посад. За таких умов складно виокремити відповідальних фахівців за реалізацію контролю, мотивації, планування та організації з-поміж учасників трудового колективу.

Особливості клієнтоорієнтованого управління відображаються у структурі персоналу організації, кадровому відборі (оскільки він є технологією, що найбільше підходить для пошуку кваліфікованих фахівців).

Функції менеджменту персоналу організації включають:

1) формування (аналіз, планування, залучення, відбір, набір) персоналу;

2) використання (адміністрування, організація ефективної праці, відповідальність та оцінка результатів праці, координація трудової діяльності, розвиток на основі навчання, мотивація, контроль, компенсації) персоналу;

3) формування іміджу організації та корпоративної культури;

4) планування службово-професійного зростання;

5) забезпечення соціальної стабільності в колективі;

6) залучення через коучинг, лізинг, аутсорсинг.

7) розвиток компетенцій співробітників на основі впровадження інновацій;

8) соціальна відповідальність персоналу.

C. Олійник зазначає, що основними завданнями менеджменту персоналу $\epsilon$ : «розробка кадрової концепції i політики, створення умов упевненості всього персоналу i кожного працівника в завтрашньому дні; створення ефективної 
Економічні науки: збірник наукових праць Луцького національного технічного університету. Серія "Регіональна економіка". Випуск 18 (71). Редкол.: відп. ред. д.е.н., професор Л.Л. Ковальська. Луиьк: ІВВ Луиького НТУ, 2021. 278 с.

кадрової системи; управління соціальним розвитком трудового колективу; організація набору і відбору персоналу у конкретних умовах; атестація персоналу та використання піi результатів; вдосконалення методів оцінки персоналу, управління внутрішніми переміщеннями і кар'єрою працівників; оцінювання ефективності та результативності системи кадрового менеджменту» [6].

Ефективне кадрове забезпечення організації, оптимальне використання потенціалу персоналу, а також його професійний, і соціальний розвиток є основними цілями формування системи менеджменту персоналу.

Завдяки системі менеджменту персоналу, яка характеризується комплексом погоджених та взаємопов'язаних кадрових важелів і методів, що спрямовані на упорядкування та ефективну організацію роботи, реалізуються функції управління в організації.

Головним в менеджменті персоналу, на думку Н. Гавкалової, $\epsilon$ «вміння працювати 3 людьми, домагатися їх зацікавленості у підвищенні свого кваліфікаційного рівня 3 метою послідовного поліпшення економічних результатів діяльності організації» [7].

Науковець А. Кібанов доводить, що «головним елементом всієї системи управління є кадри, які одночасно можуть бути як об'єктом, так і суб'єктом управління» [8].

На практиці, як стверджує Н. Бондаренко, «керівники знаходяться в постійному контакті із середовищем, що змінюється, i зобов'язані приймати рішення з урахуванням випадкових явищ і конкретних ситуацій, спираючись на власний досвід та інтуїцію. Творчі пошуки оптимального, нетривіального рішення надають управлінню рис мистецтва, адже вміння знайти розумний компроміс 3 мінімальними втратами є проявом мистецтва керуючого» [9].

Науковці А. Величко та А. Силаєв висловлюють слушну думку, що «кадрову політику доцільно розглядати як ефективний інструмент процесів реконструкції виробництва. Вона повинна бути в першу чергу орієнтована на забезпечення 
Економічні науки: збірник наукових праць Луцького національного технічного університету. Серія "Регіональна економіка". Випуск 18 (71). Редкол.: відп. ред. д.е.н., професор Л.Л. Ковальська. Луиьк: ІВВ Луцьького НТУ, 2021. 278 с.

реалізації моделі українського виробництва» [10].

Вивчення кадрової ситуації, як елемента менеджменту персоналу, необхідно здійснювати 3 метою формування власної лінії поведінки організації, що спрямована на підвищення ефективності управління персоналом, а також на зміну існуючої кадрової політики на сучаснішу, нову та більш прогресивну.

Суб' єкти господарювання використовують інструментарій економіко-статистичних методів для оцінки ефективності менеджменту персоналу організацій, зокрема, методи укрупнених нормативів, які базуються на визначенні чисельності управлінського персоналу працівників через вивчення типових структур, що узгоджуються з запланованими та фактично досягнутими показниками діяльності.

При оцінці ефективності менеджменту персоналу організацій враховується комплекс зовнішніх та внутрішніх чинників, тому доцільним також $є$ застосовування регресійних моделей.

Так, метод визначення зайнятості корисною (продуктивною) діяльністю в організаціях передбачає два варіанти розрахунків:

- використання нормативних значень показників задля визначення трудомісткості окремих видів роботи персоналу;

- використання експертних оцінок за рекомендаціями трудового колективу (показники зайнятості апарату управління середнього рівня, а також фахівців).

При визначенні дієвості та результативності менеджменту персоналу організації широке застосування здобув «метод Розенкранца» [11], з допомогою якого визначають кількість видів операцій, які виконує адміністративний персонал у поєднанні 3 функціями менеджменту за визначеними пороговими значеннями показників використання робочого часу.

Ефективність менеджменту персоналу безпосередньо впливає на рівень витрат організації та якісні результати іiі діяльності в цілому. Тому необхідним є аналіз відповідності стратегічних цілей організації кваліфікації персоналу та 
Економічні науки: збірник наукових праць Луцького національного технічного університету. Серія "Регіональна економіка". Випуск 18 (71). Редкол.: відп. ред. д.е.н., професор Л.Л. Ковальська. Луиьк: ІВВ Луиького НТУ, 2021. 278 с.

перспективним напрямкам ऑii розвитку. Зазначена оцінка обумовлює необхідність визначення рівня використання кадрового потенціалу організації, визначення шляхів нарощення компетентності співробітників, результативності праці, що сприятиме вдосконаленню напрямків діяльності та досягненню бажаного рівня розвитку. Діагностика наявного людського капіталу на різних щаблях управлінської ієрархії організації в умовах сьогодення набуває важливого значення, оскільки вона не лише виявляє вміння, навички та знання суб'єктів управління, але дозволяє виявити потенційні можливості i здібності. Компетентнісний підхід в менеджменті персоналу дозволяє враховувати активні зміни у всіх сферах діяльності організації, залежність від комплексу факторів, які впливають на розвиток культури комунікацій, а також дозволяє розкрити трудовий потенціал співробітників.

Методи оцінки персоналу, на думку Л. Федулової, доцільно подіяти на «методи індивідуальної та групової оцінки» [12].

Науковці О. Крушельницька та Д. Мельничук переконані, що повинне бути розподілення методик оцінювання персоналу на «традиційні та нетрадиційні» [13].

Колектив авторів під керівництвом А. Колота стверджує, що «із теоретичної та практичної точок зору важливо розрізняти два види оцінки персоналу: самооцінку та зовнішню оцінку. Брак одного 3 видів оцінки може сприяти розвитку навіть негативних явищ» [14].

Колектив авторів під керівництвом В. Данюка стверджує, що «за формою вираження кінцевого результату виділяють описові (оцінка подається в текстовій формі), кількісні та комбіновані методики (використовуються шкали оцінок, які дають змогу кількісно виміряти різні рівні виконання робіт на підприємстві)» [15].

Здійснивши діагностику базових методичних підходів оцінки менеджменту персоналу організації, вважаємо: існуючі методики оцінювання характеризуються значною неоднозначністю та багатогранністю, що дозволяє згрупувати їх 
Економічні науки: збірник наукових праць Луцького національного технічного університету. Серія "Регіональна економіка". Випуск 18 (71). Редкол.: відп. ред. д.е.н., професор Л.Л. Ковальська. Луиьк: ІВВ Луиького НТУ, 2021. 278 с.

за певними класифікаційними ознаками: за інструментами оцінки (практичні, імітаційні, прогностичні,); за формою викладення кінцевого результату (описові, комбіновані і кількісні).

В сучасних умовах неможливо сформувати універсальний єдино правильний методичний підхід до оцінювання ефективності менеджменту персоналу організації, оскільки він повинен бути спрямований на стратегічні цілі та завдання конкретної організації. Найкращим варіантом буде поєднання декількох методичних підходів при здійсненні такого оцінювання, а також пристосування існуючих методик до галузевої та функціональної специфіки організації, приналежності до певних ринків, а також внутрішніх і зовнішніх умов та можливостей діяльності конкретної організації.

Висновки. В результаті систематизації теоретичних засад підвищення ефективності менеджменту персоналу організації виявлено, що в сучасних умовах стрімких змін в ринковій економіці головними чинниками зростання стають універсальні навички, кваліфікація, адаптивність, продуктивність та інноваційність. Від науки управління це вимагає підвищення уваги до працівника та його професійних, особистих, ділових якостей. Тому забезпечення ефективного менеджменту персоналу організації стає першочерговим завданням бізнесу. Здійснення комплексної регулярної оцінки ефективності кадрового менеджменту за критеріями, обраними організацією, дасть змогу визначити базові пріоритети розвитку персоналу, планувати та прогнозувати його проходження по кар'єрних сходинках. За таких умов менеджмент організації отримає можливість сформувати у кожного співробітника мотивацію до розвитку компетентностей, які необхідні підприємству для досягнення стратегічних цілей.

\section{Список бібліографічного опису}

1. Горфинкель В.Я., Швандар В.А. Экономика предприятия. 4-е изд., перераб. и доп. М.: ЮНИТИ-ДАНА, 2007. 670 с.

2. Файоль А. Эмерсон Г., Тейлор Ф., Форд Г. Управление - это наука и искусство. М.: Республіка, 1992. С. 12.

3. Виноградський М.Д., Виноградська А.М., Шкапова О.М. 
Економічні науки: збірник наукових праць Луцького національного технічного університету. Серія "Регіональна економіка". Випуск 18 (71). Редкол.: відп. ред. д.е.н., професор Л.Л. Ковальська. Луцьк: ІВВ Луцького НТУ, 2021. 278 с.

Управління персоналом : навч. посібник; 2-ге вид. К. : Центр учбової літератури, 2009. 502 с.

4. Суровкин Н.В. Система управления персоналом как инновация. Служба управления персоналом: интерактивный интернет-журнал. URL: http://personaldept.h12.ru/nomer1/supinn1.html (дата звернення: 03.09.2021p.) $345 \mathrm{c}$.

5. Колот А.М. Мотивація персоналу : підручник. К. : КНЕУ, 2002.

6. Олійник С.У. Теорія та практика менеджменту персоналу : підручник. Нар. укр. акад. Х. : Вид-во НУА, 2014. 376 с.

7. Гавкалова Н.Л. Менеджмент персоналу : навч. посіб. Х. : Видавничий Дім «НЖЕК», 2004. 276 с.

8. Кибанов А.Я. Основы управления персоналом организации : учеб. по спец. 062100 «Управление персоналом». 4-е изд., доп. и перераб. М. : 2010. $695 \mathrm{c}$.

9. Бондаренко Н.В., Пантелєєв М.С., Овод М.В. Формування сучасних систем управління персоналом підприємства. Комунальне господарство міст Харків, 2014. С. 267-272.

10. Величко А.В., Силаєв А.В. Особливості формування кадрової політики організації в сучасних умовах. Бюлетень Міжнародного Нобелівського економічного форуму. 2012. № 1 (5). Том 2. С. 38-44.

11. Данюк В.М., Петюх В.М., Цимбалюк С.О. Менеджмент персоналу: навч. посібник. К. : КНЕУ, 2004. 398 с.

12. Федулова Л.І. Менеджмент організацій: підручник. К.: Либідь, 2004. $448 \mathrm{c}$.

13. Крушельницька О.В., Мельничук Д.П. Управління персоналом: Навчальний посібник. Видання друге, перероблене й доповнене. К. : «Кондор», 2005. 308 с.

14. Колот А.М., Грішнова О.А., Герасименко О.О. Економіка праці та соціально-трудові відносини; за наук. ред. А.М. Колота. Київ: КНЕУ, 2009. $711 \mathrm{c}$.

15. Данюк В.М., Колот А.М., Суков Г.С. Управління персоналом. Київ: КНЕУ; Краматорськ: НКМЗ, 2013. 666 с.

\section{References}

1. Horfynkel' V.Ya., Shvandar V.A. Эkonomyka predpryyatyya. 4-e yzd., pererab. y dop. M.: YuNYTY-DANA, 2007. $670 \mathrm{~s}$.

2. Fayol' A. Эmerson H., Teylor F., Ford H. Upravlenye - эto nauka y yskusstvo. M.: Respublika, 1992. S. 12.

3. Vynohrads'kyy M.D., Vynohrads'ka A.M., Shkapova O.M. Upravlinnya personalom : navch. posibnyk ; 2-he vyd. K. : Tsentr uchbovoyi literatury, 2009. $502 \mathrm{~s}$.

4. Surovkyn N.V. Systema upravlenyya personalom kak ynnovatsyya. Sluzhba upravlenyya personalom: ynteraktyvnыy ynternet-zhurnal. URL: http://personaldept.h12.ru/nomer1/supinn1.html (data zvernennya: 03.09.2021r.)

5. Kolot A.M. Motyvatsiya personalu : pidruchnyk. K. : KNEU, 2002. 
Економічні науки: збірник наукових праць Луцького національного технічного університету. Серія "Регіональна економіка". Випуск 18 (71). Редкол.: відп. ред. д.е.н., професор Л.Л. Ковальська. Луцьк: ІВВ Луцького НТУ, 2021. 278 с.

$345 \mathrm{~s}$.

6. Oliynyk S.U. Teoriya ta praktyka menedzhmentu personalu : pidruchnyk. Nar. ukr. akad. Kh. : Vyd-vo NUA, 2014. 376 s.

7. Havkalova N.L. Menedzhment personalu : navch. posib. Kh. : Vydavnychyy Dim «INZhEK», 2004. 276 s.

8. Kybanov A. Ya. Osnovы upravlenyya personalom orhanyzatsyy : ucheb. po spets. 062100 «Upravlenye personalom». 4-e yzd., dop. y pererab. M. : 2010. $695 \mathrm{~s}$.

9. Bondarenko N.V., Pantelyeyev M.S., Ovod M.V. Formuvannya suchasnykh system upravlinnya personalom pidpryyemstva. Komunal'ne hospodarstvo mist Kharkiv, 2014. S. 267-272.

10. Velychko A.V., Sylayev A.V. Osoblyvosti formuvannya kadrovoyi polityky orhanizatsiyi v suchasnykh umovakh. Byuleten' Mizhnarodnoho Nobelivs'koho ekonomichnoho forumu. 2012. \# 1 (5). Tom 2. S. 38-44.

11. Danyuk V.M., Petyukh V.M., Tsymbalyuk S.O. Menedzhment personalu: navch. posibnyk. K. : KNEU, 2004. 398 s.

12. Fedulova L.I. Menedzhment orhanizatsiy: pidruchnyk. K.: Lybid', 2004. $448 \mathrm{~s}$.

13. Krushel'nyts'ka O.V., Mel'nychuk D.P. Upravlinnya personalom: Navchal'nyy posibnyk. Vydannya druhe, pereroblene y dopovnene. K. : «Kondor», 2005. $308 \mathrm{~s}$.

14. Kolot A.M., Hrishnova O.A., Herasymenko O.O. Ekonomika pratsi ta sotsial'no-trudovi vidnosyny; za nauk. red. A.M. Kolota. Kyyiv: KNEU, 2009. $711 \mathrm{~s}$.

15. Danyuk V.M., Kolot A.M., Sukov H.S. Upravlinnya personalom. Kyyiv: KNEU; Kramators'k: NKMZ, 2013. 666 s.

DOI: https://doi.org/10.36910/2707-6296-2021-18(71)-21 